ben and 'The Birth of Sexuality'," JQR 96 (2006) 65-94. - Stone, M. E., “The Genealogy of Bilhah,” DSD 3 (1996) 2036. -Weinstein, B., "Why Exclude Bilhah and Zilpah?," Journal of the Central Conference of the American Rabbis 57/1 (2010) 92-99.

Barry Dov Walfish

\section{Bilhah (Place)}

A location in Simeon (MT Bilhâ; $1 \mathrm{Chr} 4: 29)$ also called Baalah (Josh $15: 29)$ and Balah (Josh 19:3). It may be the same location as Baalath (Josh 19:44).

Nyasha Junior

\section{Bilhan}

There are two persons named Bilhan (MT Bilhān) in the $\mathrm{HB} / \mathrm{OT}$.

\section{Son of Ezer}

Bilhan is the name of one of the sons of Ezer who was a descendent of Seir the Horite in Edom (Gen $36: 27)$. He is also listed in the parallel genealogy in 1 Chr $1: 42$. The Genesis list of Seir's sons is inclusive and very methodical, while the Chronicler's list is concise and merely a framework of names.

\section{Son of Jediael}

Bilhan is the firstborn son of Jediael and thus grandson of Benjamin, according to the genealogical clan list in $1 \mathrm{Chr} 7: 10$. He fathered Jeush, Benjamin, Ehud, Chenaanah, Zethan, Tarshish, and Ashishahar (cf. Gen 46:21; Num 26:38). This census registry may actually be for the tribe of Zebulun, since the Benjaminite list repeats with slight differences in 1 Chr $8: 1-40$.

Bibliography: - Japhet, S., I and II Chronicles (OTL; Philadelphia, Pa. 1993).

Craig Bowman

\section{Bill}

$\rightarrow$ Divorce

\section{Billerbeck, Paul}

Ernst Friedrich Paul Billerbeck (1853-1932) was born on April 4, 1853 in Schönfließ, now Trzcinsko Zdroj, Poland, as son of a farmer. He went to school in Schönfließ, then in Königsberg/Neumark, and studied theology in Greifswald and Leipzig. Among his teachers were Julius Wellhausen, Hermann Cremer and Franz Delitzsch. Ordained in 1879, he first became a curate in Wintershagen and then a parson in Zielenzig, now Sulecin (Poland). Having to care for a family with nine children, he moved in 1889 to Heinersdorf, now Drogomin (Poland), where he was also responsible for the pastoral work in Trebow and Schmagorei. In 1915 he retired and moved to Frankfurt a.d.O., where he died on December 23, 1932.

During his years at Heinersdorf he wrote about Jewish subjects, like "Abrahams Leben und Bedeutung für das Reich Gottes nach der älteren Haggada," "Eine Jüdische Paradiesschilderung," "Hat die alte Synagoge einen praeexistenten Messias gekannt?”. We do not know where Billerbeck's interest in Jewish subjects came from, how he learned to read rabbinic texts or how he was able to collect them. All his articles were published from 1899 to 1918 in the journal Nathanael: Zeitschrift für die Arbeit der evangelischen Kirche an Israel, edited by Hermann L. Strack. On account of them Strack urged Billerbeck to write a theology of the Talmud. But he was only willing to collect rabbinical parallels to the NT. The result was the Kommentar zum Neuen Testament aus Talmud und Midrasch (4 vols., München 1922-28). This commentary is still called "StrackBillerbeck," although Billerbeck was its only author. It has become the most important repository of rabbinic and earlier Jewish texts which can help in the understanding of the NT. Its abuse as a shortcut to the Jewish sources out of context has been rightly criticized. But used critically as a collection of texts to be studied in their wider context and ideally in their original languages, it is still of the greatest value.

In 1923 he became Doctor honoris causa of the University of Greifswald; the University of Königsberg also awarded him an honorary doctorate. He was buried in Heinersdorf, now Drogomin, but the cemetery is decayed and it is impossible to find his grave.

Bibliography: -Jeremias, J., "Paul Billerbeck in memoriam,” Theologische Blätter 12/2 (1933) 33-36. - Jeremias, J., “Billerbeck, Paul (1853-1932)," TRE 6 (Berlin/New York 1980) 640-42.

Julia Männchen

\section{Bilqīs}

$\rightarrow$ Sheba, Queen of

\section{Bilshan}

Bilshan (MT Bilšān; Ezra 2:2; Neh 7:7) was one of the leaders who returned to Jerusalem from Babylon with Zerubbabel. In 1Esd 5:8 he is called "Beelsarus." His name is possibly an abbreviated form derived from the Akkadian Bel-šunnu. Bilshan's precise leadership role and the nature of the list of returnees in these parallel texts are unknown.

Craig Bowman 